\title{
Settlement of Iceland scallop Chlamys islandica spat in response to hydroids and filamentous red algae: field observations and laboratory experiments*
}

\author{
Michel Harvey, Edwin Bourget, Gilles Miron \\ GIROQ, Département de biologie, Université Laval, Ste.-Foy (Québec), Canada G1K 7P4
}

\begin{abstract}
Sampling carried out in the Baie des Chaleurs (Gulf of St. Lawrence, Canada) in 1990 and 1991 showed that newly settled Iceland scallop Chlamys islandica spat were not randomly distributed on the sea bottom. Various inorganic (sand, gravel, pebbles, shells of different species) and organic (algae and animals) substrata were examined. Twenty times more post-larvae were found on perisarcs of the dead hydroid Tubularia larynx than on live hydroids and red algae (another preferred natural substratum). Maximum densities, up to $300 \mathrm{spat}^{-1}$ (dry wt) of hydroids, were observed on a mooring line at $2 \mathrm{~m}$ from the bottom. Laboratory experiments carried out to determine whether attachment behaviour of post-larvae could contribute to the observed distribution of spat showed that: (1) spat can resettle easily when dislodged from their substratum; (2) independent of their origin, over $60 \%$ spat preferred to resettle on dead rather than live hydroids, filamentous red algae (Ptilota serrata and Phycodrys rubens) or fishing line (used as control); and (3) they also preferred to resettle on the type of substratum to which they were previously attached. Different hypotheses concerning active and passive larval settlement processes and post-larval redispersion strategy are proposed to explain this relationship between scallops and hydroids.
\end{abstract}

\section{INTRODUCTION}

Trends in scallop landings from major areas of production exhibit wide temporal fluctuations which are mostly related to irregular recruitment and overfishing (Orensanz et al. 1991). In an effort to stabilise yields, the possibility of scallop cultivation has been examined in both Europe (see review in Thouzeau 1991) and America (Naidu et al. 1981, Ruzzante \& Zaixso 1985). The culture technique, based on the Japanese method, consists of allowing spat to settle in collector bags, growing them to market size in cages in the sea, or using them to restock natural beds (Brand et al. 1980, Ventilla 1982). The success of these methods, therefore, is largely dependent on the recruitment of scal-

\footnotetext{
- Contribution to the program of GIROQ (Groupe Interuniversitaire de Recherches Océanographiques du Québec)
}

lops to the collector bags. Results of experimental scallop spat collection carried out in European and American scallop beds showed a high spatial variability of spat yield on collectors (see 'Discussion' for references). In all cases the success of collections was far below that obtained with Patinopecten yessoensis in Japan.

The purpose of scallop spat collectors is to provide a suitable substratum for settlement of planktonic larvae and then to prevent the settled spat from escaping (Brand et al. 1980). Attempts have been made to increase the yields of collectors by modifying: (1) their size and shape; $(2)$ the material offered to larvae for settlement (scallop shells, polythene film and 'Netlon'); and/or (3) the mesh size of the outer bag. Since approximately 1970, collectors have generally been constructed of used monofilament gill netting contained within an onion bag (Brand et al. 1980). Behavioural aspects of larval settlement, including substratum 
selection and byssal attachment, have not been taken into account in the design of spat collectors, probably because little is known about these aspects of recruitment in scallops. Substantial improvement in collecting ability could be achieved by better knowledge of the settlement behaviour of scallop larvae in response to natural substrata, and incorporation of this knowledge into the design of collectors.

Larval settlement behaviour and responses to settlement cues have been intensively studied in many species of sessile marine invertebrate (see reviews by Crisp 1974, Burke 1983, Bourget 1988 and Pawlik 1992). Settlement of benthic invertebrates larvae is influenced by water flow, chemical cues, substratum type and texture, light, larval competence, substratum conditioning, molecular and bacterial films and community structure (Rittschof et al. 1984, Roberts et al. 1991). In semi-mobile invertebrates such as scallops, which usually display an initial phase of byssal attachment (Fig. 1), mechanisms of microhabitat selection at settlement and recruitment processes are poorly understood due to inadequate knowledge of the requirements, behaviour and distribution of newly settled post-larvae. Scallop larvae are known to settle on a wide range of filamentous epibenthic substrata (Larsen \& Lee 1978, Brand et al. 1980, Sause et al. 1987. Minchin 1992). On the other hand, despite its evolutionary significance and great ecological importance, byssal-attachment has seldom been studied in any scallop species (Brand 1991). Our primary objectives in the present study were: (1) to establish if Iceland scallop Chlamys islandica spat prefer particular

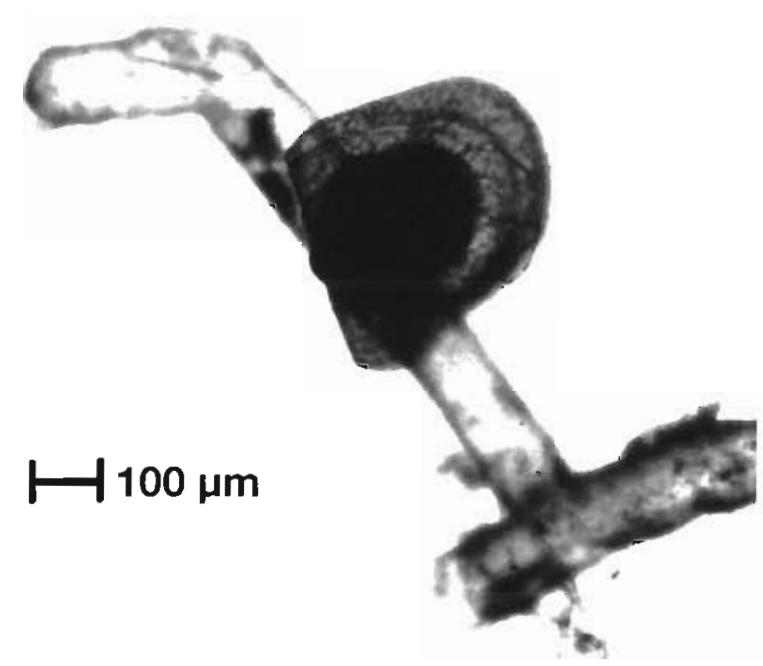

Fig. 1 Chlamys islandica. Iceland scallop spat attached to the perisarc of the hydroid Tubularia larynx substrata on the sea bottom; and (2) to determine whether post-settlement behaviour could contribute to the observed distribution of spat.

\section{METHODS}

Study site and data collection. Field studies were carried out in the Baie des Chaleurs (Québec, Canada), in 1990 and 1991. In October and November 1990, during and immediately following scallop larval settlement, qualitative samples were made of various inorganic and organic substrata (e.g. sand, gravel, pebbles and empty shells, different species of filamentous and nonfilamentous algae and different species of animals such as hydroids and bryozoans). Samples were collected by scuba divers within 5 areas of approximately $100 \mathrm{~m}^{2}$ each. Inside these areas the number of replicate samples depended on the abundance of each particular substratum (see Table 1). Samples were also collected along a mooring line (18 $\mathrm{m}$ depth) in late November. The former sampling program was repeated in 1991. At this time, only the hydroid Tubularia larynx and species of red algae which had either filamentous (Ptilota serrata) or subdivided (Phycodrys rubrens) thalli were collected. Ten samples of each substratum were collected within an area of approximately $500 \mathrm{~m}^{2}$. Hydroids were divided in 2 groups representing dead and live organisms. Colonies were considered to be dead when only their perisarc, the nonliving chitinous envelope, was present (Fig. 2A). Live hydroids had zooids and both the perisarc and its living content, the coenosarc (Fig. 2B). The pinkish colour of the live hydroids contrasted markedly with the greyish colour of the dead ones. Also, under the scanning electron microscope, the dead $T$. larynx appeared fouled by large quantities of microalgae (mainly benthic and planktonic diatoms) and bacteria. In both years, samples were frozen at $-20^{\circ} \mathrm{C}$ until examination in the laboratory.

In the laboratory, each sample, except those of sand and gravel substrata, was rinsed in a 500 ppm solution. of sodium hypochlorite for $5 \mathrm{~min}$. This procedure dislodged spat from the substratum by dissolving the byssal threads (Bourne et al. 1989). The solution was filtered on a $100 \mu \mathrm{m}$ plankton net and scallop spat were counted under a stereomicroscope $(60 \times)$. Sand and gravel samples were examined directly under the stereomicroscope $(60 \times)$. Density of scallop post-larvae in each sample was calculated by dividing the number of spat by wet wt $(\mathrm{g})$, dry wt $(\mathrm{g})$ or total area $\left(\mathrm{cm}^{2}\right)$ available for settlement for each sampled substratum. In 1990, the wet wt of red algae and hydroids was measured. In 1991, the total area available for settlement on each substratum sampled was estimated and the 
dry wt was measured after drying to constant weight at $70^{\circ} \mathrm{C}$ for $24 \mathrm{~h}$. To determine the total area available for settlement: (1) 10 subsamples of different size were collected from each type of substratumi (2) each subsample was carefully spread on a sheet of paper so as to avoid any overlap between parts; (3) each subsample was digitized, and the total area estimated using image analysis (the software 'Image' for Macintosh); and (4) dry wt of each subsample was estimated after drying to constant weight at $70^{\circ} \mathrm{C}$ for $24 \mathrm{~h}$. The existence of a linear relationship between total area and dry wt of a subsample was confirmed by least-squares linear regressions (hydroids: area $\left(\mathrm{cm}^{2}\right)=-0.501+$ 0.013 (wt, mg), $\mathrm{r}^{2}=0.83, \mathrm{n}=27$; Ptilota serrata: area $=$ $1.628+7.497(\mathrm{wt}), \mathrm{r}^{2}=0.98, \mathrm{n}=10 ;$ Phycodrys rubens: area $=9.098+10.174(\mathrm{wt}), \mathrm{r}^{2}=0.95, \mathrm{n}=10$ ). Finally, the total area available for settlement was determined for each sample of each type of substratum sampled in 1991 by using dry wt of the total sample and the regression equations obtained in the above procedure.

At the end of the 1991 settlement season (midNovember), dead hydroids were sampled at $2 \mathrm{~m}$ intervals along 3 different mooring lines (to $18 \mathrm{~m}$ depth) which had been immersed for 7 mo. Mean density (spat $\mathrm{g}^{-1}$ dry wt hydroid $\pm \mathrm{SE}$ ) of scallop post-larvae attached to these hydroids was estimated for each sample as above.

Laboratory experiments. Several types of experiments were carried out to examine the ability of postlarvae to select and resettle on various surfaces after their removal from a number of natural substrata.

General experimental procedure: Scallop spat for resettlement assays were obtained from natural filamentous substrata (dead and live hydroids; Ptilota serrata, Phycodrys rubens) collected daily. Scallop post-larvae were easily dislodged from hydroids and algae by shaking them in a bucket of cold seawater. The dislodged material was put in a petri dish and scallop spat collected under a stereomicroscope $(60 \times)$ equipped with a cold light. Spat had a shell length varying from 250 to $500 \mu \mathrm{m}$; care was taken to use individuals covering the entire size range for each assay. Spat were placed in a refrigerator at $8^{\circ} \mathrm{C}$ within $15 \mathrm{~min}$ of collection. All experiments were performed in the dark in a refrigerator at $8^{\circ} \mathrm{C}$. Assays were conducted in $70 \times 50 \mathrm{~mm}$ crystallizing dishes (Corning no. 420630) filled with $100 \mathrm{ml}$ of filtered seawater (Whatman, GF/C). Data were expressed as the \% of the initial number of post-larvae which had resettled by the end of the assay.

Rate of resettlement: Preliminary observations showed that scallop post-larvae resettled quickly on filamentous substrata in the laboratory. The rate of resettlement of spat was studied under controlled conditions. Experiments were carried out using spat col-
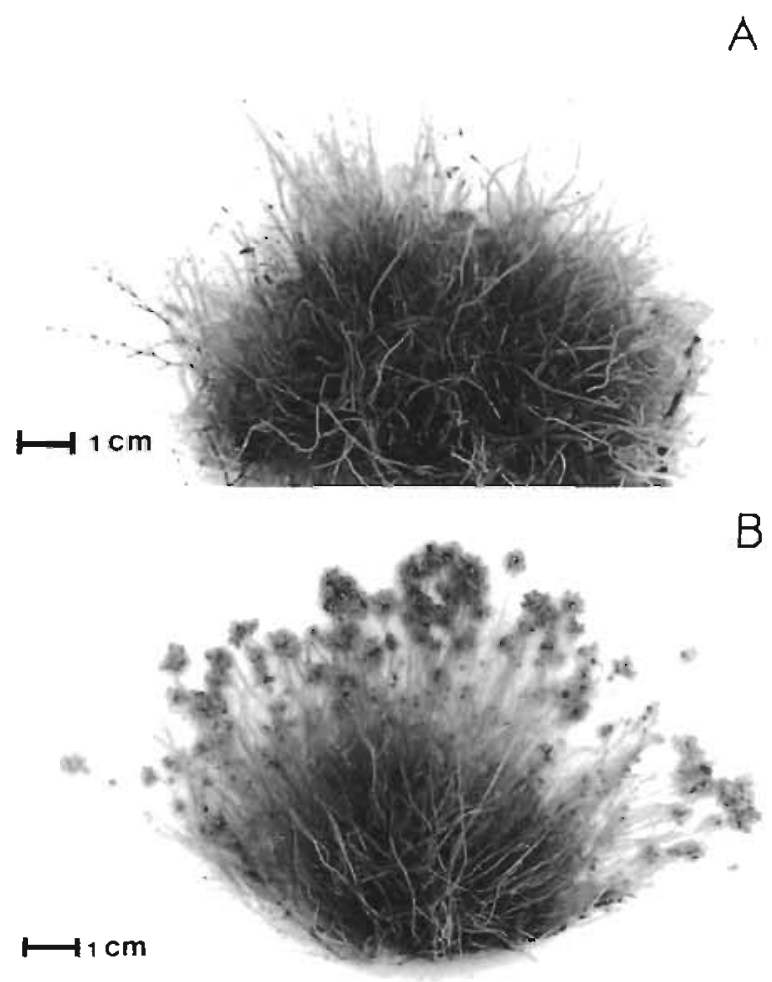

Fig. 2. Tubularia larynx. (A) Dead and (B) live colony of hydroids

lected from dead hydroids. Fifteen spat were placed in crystallizing dishes (see above) containing 5 perisarcs of dead hydroids $(3 \mathrm{~cm}$ long). The number of resettled spat were counted in 3 replicates every $2 \mathrm{~h}$ for a period of $12 \mathrm{~h}$. The experiment was repeated 3 times using 3 different batches of spat.

Substratum selectivity - spat originating from dead hydroids: This experiment was designed to test substratum preferences of post-larvae at resettlement. The assay was carried out with spat collected from dead hydroids. Groups of 15 spat were offered 1 of 5 different substrata for attachment, including: perisarcs of dead (DH) and live ( $\mathrm{LH}$ ) hydroids, the algae Ptilota serrata $(P S)$ and Phycodrys rubens $(P r)$ and threads of monofilament fishing line (diameter $=0.3 \mathrm{~mm}$ ) as a control (Con). Assays were replicated 3 times. Each branch or perisarc was $3 \mathrm{~cm}$ long and the number of units in a dish varied among types of substrata in order to give an approximately equal area (determined by eye) for spat attachment ( 5 perisarcs of dead and live hydroids, 5 threads of fishing line and 3 branches each of Ptilota serrata and Phycodrys rubens). The number of post-larvae resettling on each substratum was counted after a period of $12 \mathrm{~h}$. The experiment was repeated 3 times using 3 different batches of spat. 
Table 1 Chlamys islandica. Distribution of scallop spat on various natural substrata collected in Baie des Chaleurs in November 1990

\begin{tabular}{|c|c|c|}
\hline Substratum & $\begin{array}{c}\text { No. of samples } \\
\text { examined }\end{array}$ & $\begin{array}{l}\text { No, of scallop } \\
\text { spat observed }\end{array}$ \\
\hline \multicolumn{3}{|l|}{ Inorganic substrata } \\
\hline Sand & 9 & 0 \\
\hline Gravel & 29 & 6 \\
\hline Pebbles & 28 & 0 \\
\hline \multicolumn{3}{|l|}{ Empty tests and shells } \\
\hline Sand dollar Echinarachnius parma & 25 & 0 \\
\hline Scallop Placopecten magellanicus & 5 & 0 \\
\hline Mussel Mytilus edulis & 5 & 0 \\
\hline \multicolumn{3}{|l|}{ Organic substrata } \\
\hline \multicolumn{3}{|l|}{ Algae } \\
\hline \multicolumn{3}{|l|}{ Phaeophytes } \\
\hline Agarum cribosum & 13 & 1 \\
\hline \multicolumn{3}{|l|}{ Rhodophytes } \\
\hline Polysiphonia sp. & 1 & 0 \\
\hline Ptilota serrata & 12 & $31^{a}$ \\
\hline Phycodrys rubens & 22 & $53^{u}$ \\
\hline Phyllophora truncata & 3 & $83^{a}$ \\
\hline \multicolumn{3}{|l|}{ Animals } \\
\hline \multicolumn{3}{|l|}{ Hydroids } \\
\hline Tubularia larynx & 7 & $144^{\mathrm{a}}$ \\
\hline \multicolumn{3}{|l|}{ Bryozoans } \\
\hline Flustra foliacea & 3 & 0 \\
\hline Byssal thread of Mytilus edulis & 6 & 6 \\
\hline Byssal thread of $M$. edulis $+T$. larynx & 1 & $48^{\mathrm{a}}$ \\
\hline
\end{tabular}

which post-larvae were collected from 3 different substrata, including live hydroids, Ptilota serrata and Phycodrys rubens. Each assay was identical to those described in the preceding experimental protocol except that 10 spat per dish were used and each assay was carried out only once. These modifications were due to the limited availability of spat from substrata other than dead hydroids.

Statistical analyses. Field study: For filamentous substrata collected in 1991, density of scallop spat (per gram of substratum and per $100 \mathrm{~cm}^{2}$ ) was compared among substrata using a Kruskal-Wallis test followed by Tukey's multiple comparisons test.

Laboratory experiments: Statistical analyses were carried out on arcsinetransformed data. This transformation increased homogeneity of variance and normalized the data. All replicates in which no spat resettled were given a value of $1 /(4 n)$ to improve the arcsine transformation (Zar 1984). When variances were homogeneous and no major departures from normality were observed, a 1-way ANOVA was used

Substratum selectivity - spat originating from different substrata: Substratum selection by spat at resettlement may be affected by the type of substratum to which they were previously attached ('spat source'). This hypothesis was tested by conducting 3 assays in
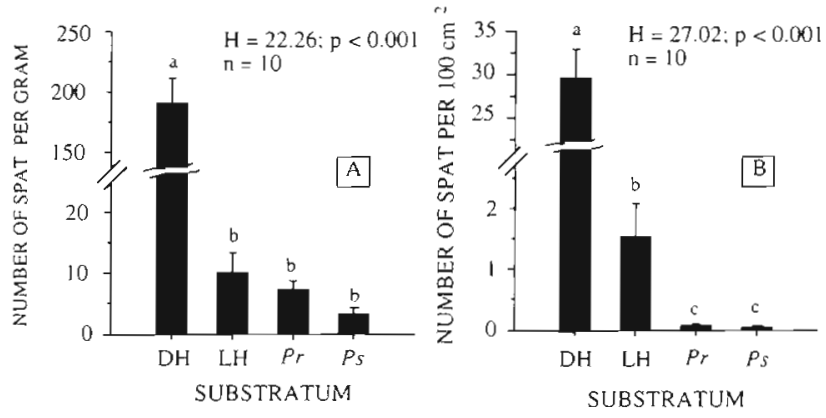

Fig. 3. Chlamys islandica. Mean number ( $\pm S E$ ) of Iceland scallop spat settled on different filamentous substrata collected in 1991 in Baie des Chaleurs. Results are expressed in number of spat per gram of dry wt material (A), and in number of spat per unit area available for settlement (B). DH: dead hydroids; LH: live hydroids; Pr: Phycodrys rubens; Ps: Ptilota serrata. A nonparametric analysis of variance (Kruskal-Wallis test) was used in both cases. Bars having dissimular letters above them differ significantly from each other by Tukey's $w$ procedure and means were compared by Tukey's multiple comparison test. Otherwise, we used a nonparametric randomized block analysis of variance (Friedman's test) with multiple observations per cell (Conover 1980) or a Kruskal-Wallis test followed by post-hoc comparisons among means by Tukey's $w$ procedure (Zar 1984). The test used in each assay is indicated in the figure legend.

\section{RESULTS}

\section{Field study}

In the field, recruitment of Iceland scallop spat is patchy (Table 1). Newly settled spat were mainly found on only a few types of substrata, particularly the perisarc of dead hydroids Tubularia larynx. In 1990 , spat were mostly found on red algae and hydroids (Table 1). Over 144 post-larvae per $100 \mathrm{~g}$ (wet wt) of material were collected on T. larynx. In 1991, there were significant differences among filamentous natural substrata in the number of spat settled, in both number of spat per gram (Fig. 3A) and per $100 \mathrm{~cm}^{2}$ (Fig. 3B). There were 20 times more scallop post-larvae attached to dead than to live hydroids. 


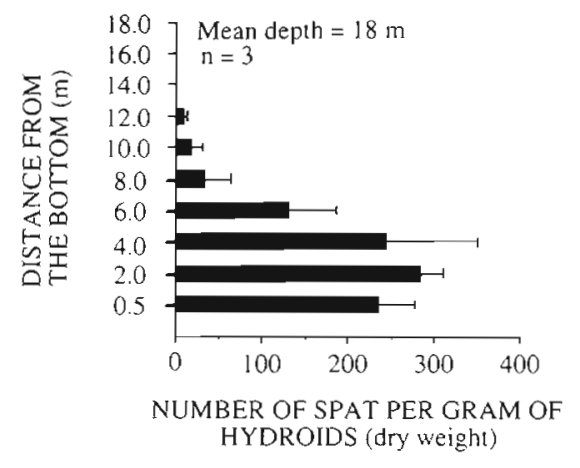

Fig. 4. Chlamys islandica. Mean number ( \pm SE) of Iceland scallop spat collected from dead hydroids colonizing mooring lines immersed since the preceding spring (May)

Settlement of Chlamys islandica occurred between 0 and $12 \mathrm{~m}$ above the sea floor (Fig. 4). A maximum mean of $283 \pm 26$ ind. $\mathrm{g}^{-1}$ (dry wt) of hydroids was observed $2 \mathrm{~m}$ from the bottom. Settlement decreased at $0.5 \mathrm{~m}$ above the seabed.

\section{Laboratory experiments}

The number of spat resettling on the perisarc of dead hydroids increased significantly with time (Fig. 5). Further, there were significant differences among sampling times $\left(\chi^{2}=30.37 ; \mathrm{p}<0.001, \mathrm{n}=9\right)$. Over $70 \%$ of post-larvae resettled within $12 \mathrm{~h}$ from the beginning of the experiment. No significant increase in the number of resettled spat was observed between Hours 2 and 8 (when ca $30 \%$ of spat had resettled), but a significant increase occurred at Hours 10 and 12 when 50 and $70 \%$, respectively, of spat had resettled (Fig. 5).

Single choice experiments indicate that Iceland scallop spat resettled preferentially on dead hydroids

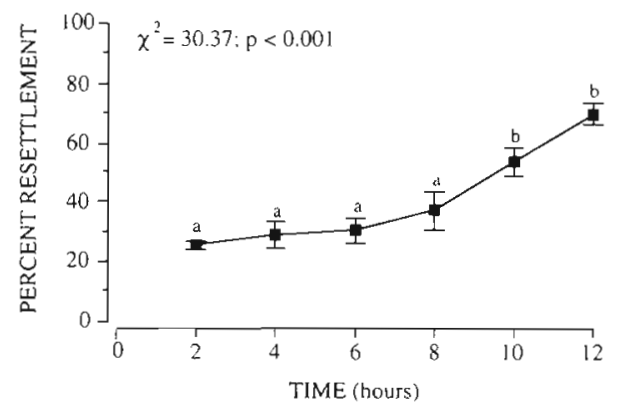

Fig. 5. Chlamys islandica. Percent $( \pm S E)$ of Iceland scallop spat resettling on the perisarc of dead hydroids against time. Statistical test used: a nonparametric randomized block analysis of variance (Friedman's test) with multiple observations per cell followed by Tukey's multiple comparisons test. Points with dissimilar letters above them are significantly different from each other by Tukey's $w$ procedure
Tubularia larynx than on the other substrata used in the experiment ( $T$. larynx live, Phycodrys rubens, Ptilota serrata and control $)\left(\chi^{2}=19.33 ; \mathrm{p}<0.001, \mathrm{n}=9\right)$. Sixty percent of spat resettled on the perisarc of dead hydroids compared to approximately $20 \%$ for other substrata (Fig. 6A).

There were significant substratum effects in each of the 3 experiments carried out with spat collected on different substrata (Fig. $6 \mathrm{~B}$ to D). Resettlement was higher on dead hydroids in each of the 3 assays. Attractiveness to the other substrata was, however, increased when spat originated from the corresponding substrata (Fig. $6 \mathrm{~B}$ to D). In all assays carried out with spat collected from live hydroids (Fig. 6B), Ptilota serrata (Fig. 6C) and Phycodrys rubens (Fig. 6D), the second most attractive substratum was the one on which spat were originally attached. In assays carried out with spat collected from live hydroids (Fig. 6B), there were significantly greater spat resettlement on dead than on live hydroids, live hydroids being the second most attractive substratum (Fig. 6B). However, in experiments carried out with spat collected from
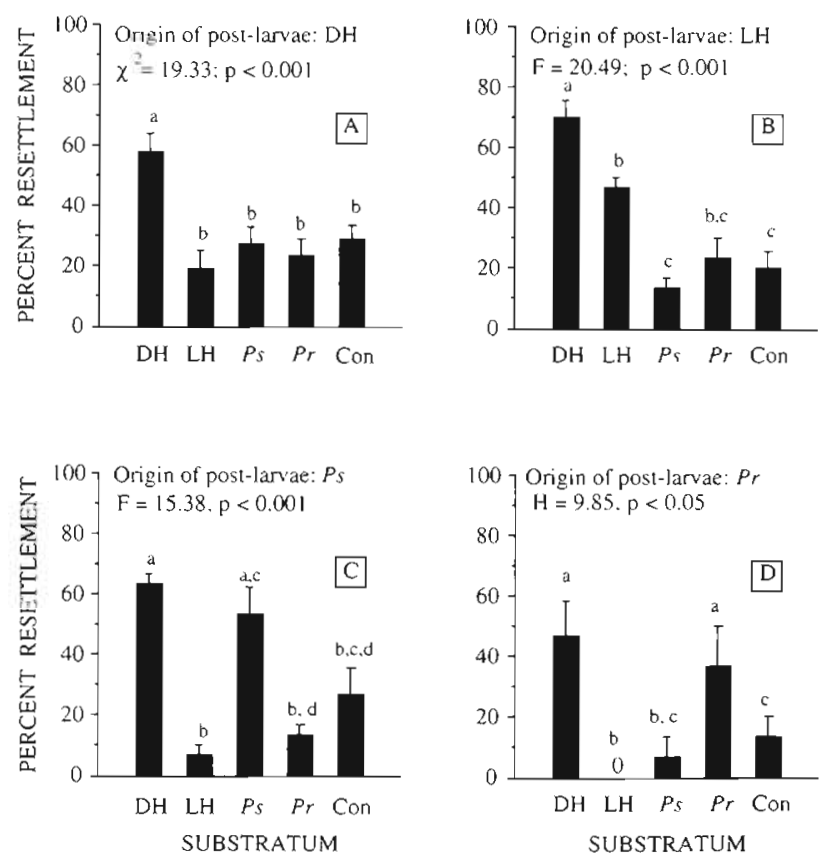

Fig. 6. Chlamys islandica. Percent ( $\pm \mathrm{SE}$ ) of Iceland scallop spat resettling on different filamentous substrata in experiments carried out with spat originating from (A) dead hydroids, (B) live hydroids, (C) Ptilota serrata and (D) Phycodrys rubens. Statistical tests used were: a nonparametric randomized block analysis of variance (Friedman's test) with multiple observations per cell (assay A), a 1-way ANOVA (assays B and $C$ ) and a Kruskal-Wallis test (assay D). Bars having dissimilar letters above them differ significantly from each other by Tukey's $w$ procedure. DH: dead hydroids; LH: live hydroids; Pr: Phycodrys rubens; Ps: Ptilota serrata; Con: control 
Ptilota serrata (Fig. 6C) and Phycodrys rubens (Fig. 6D), no significant difference was observed between number of individuals resettled on both dead hydroids and the second most attractive substratum (Ptilota serrata or Phycodrys rubens).

\section{DISCUSSION}

\section{Relationship between newly settled scallop spat and dead hydroids}

Our distributional data suggest that scallop larvae exhibit a preference for filamentous substrata (hydroids and red algae), particularly the perisarc of dead Tubularia larynx. Spat of a number scallop species have been reported to settle on variaty of filamentous organisms [e.g. Pecten maximus and Chlamys opercularis (>1 mm) on hydroids and bryozoans (Dare \& Bannister 1987); giant scallop Placopecten magellanicus juveniles (size range 0.2 to $2.8 \mathrm{~mm}$ ) on hydroids, amphipod tubes and grains of sand (Larsen \& Lee 1978); Pecten alba (>2 mm) on filamentous algae and detached fronds of seagrass (Sause et al. 1987)]. In contrast, no apparent post-larvae substratum selectivity was observed in Pecten maximus, but surfaces to which they attached were generally free of silt (Thouzeau 1989, Minchin 1992). These results on various pectinid species and our observations suggest that scallop larvae prefer to settle on a wide range of filamentous epibenthic substrata. In doing so, the newly settled individuals are probably protected from silting on bottom sediments (Merrill \& Edwards 1976), while at the same time better positioning themselves for feeding on suspended particles. Other shore species use analogous adaptations for settlement, particularly Mytilus edulis (Bayne 1964).

In our study recruitment increased with depth before decreasing just above the seabed. Round et al. (1961) reported that settlement of Chlamys sp. and Pecten maximus on the hydroid Sertularia operculata was greater above the seabed (on suspended ropes) than on the bottom. According to many studies on pectinid species (Table 2), maximum settlement occurs, in the majority of species, between 1 and $3 \mathrm{~m}$ above the seabed. Some species (e.g. C. opercularis, $P$. maximus

Table 2. Summary of data on depth of maximum settlement and the number of spat on artificial collectors in various pectinid species. Artificial collectors were made up of fine-meshed onion bags containing known amounts of monofilament gill netting. Concentrations of spat on collectors (ind. $100 \mathrm{~g}^{-1}$ ) were calculated by weight of gill net used per collector in each study. Results of the present study were obtained on dead hydroids sampled at $2 \mathrm{~m}$ from the seabed on mooring line

\begin{tabular}{|c|c|c|c|c|}
\hline Species & Location & $\begin{array}{c}\text { Depth of } \\
\text { maximum } \\
\text { settlement } \\
\text { (m above seabed) }\end{array}$ & $\begin{array}{c}\text { Spat } \\
\text { yields on } \\
\text { collectors } \\
\text { (ind. } 100 \mathrm{~g}^{-1} \text { ) }\end{array}$ & Source \\
\hline Pecten maximus & Baie de St-Brieuc, France & $1-3$ & 160 & Buestel et. al (1979) \\
\hline P. maximus & Baie de St-Brieuc, France & 1.4 & 12 & Thouzeau (1991) \\
\hline P. maximus & Isle of Man, England & 5.5 & 2 & Brand et al. (1980) \\
\hline P. alba & Port Phillip Bay, Australia & 2.5 & 175 & Sause et al. (1987) \\
\hline $\begin{array}{l}\text { Leptopecten latiauratus, } \\
\text { wide-eared scallop }\end{array}$ & San Diego, California, USA & - & 49 & Phleger \& Cary (1983) \\
\hline $\begin{array}{l}\text { Placopecten magellanicus, } \\
\text { giant scallop }\end{array}$ & $\begin{array}{l}\text { Gulf of St. Lawrence, } \\
\text { Newfoundland, Canada }\end{array}$ & - & 73 & Naidu et al. (1981) \\
\hline P. magellanicus & $\begin{array}{l}\text { lles-de-la-Madeleine, } \\
\text { Québec, Canada }\end{array}$ & - & 171 & Cliche et al. (1991) \\
\hline Patinopecten yessoensis & Japan & - & $1.2 \times 10^{4}$ & Ventilla (1992) \\
\hline Chlamys islandica & Balsfjord, Norway & $2.0-10$ & - & Wallace (1981-1982) \\
\hline C. islandica & Breidafjördur, Iceland & $2.5-10$ & 10 & Thorarinsdottir (1991) \\
\hline C. islandica & $\begin{array}{l}\text { Baie des Chaleurs, } \\
\text { Québec, Canada }\end{array}$ & 2.0 & $3.0 \times 10^{4}$ & This study \\
\hline C. varia & Baie de St-Brieuc, France & 1.4 & 36 & Thouzeau (1991) \\
\hline C. opercularis & Baie de St-Brieuc, France & 1.4 & 12 & Thouzeau (1991) \\
\hline C. opercularis & Isle of Man, England & 8.5 & 13 & Brand et al. (1980) \\
\hline C. tehuelchus & Gulf of San José, Argentina & - & 175 & Ruzzante \& Za1xso (1985) \\
\hline $\begin{array}{l}\text { Hinnites multirugosus, } \\
\text { rock scallop }\end{array}$ & San Diego, California, USA & - & 5 & Phleger \& Cary (1983) \\
\hline
\end{tabular}


and $P$. alba), however, settled at highest densities in midwater (Brand et al. 1980, Sause et al. 1987). Others (e.g. C. islandica) show no variation in settlement between 2 to $10 \mathrm{~m}$ above the seabed (Wallace 1981 1982, Thorarinsdottir 1991). Behaviour, position of larvae in the water column (Sause et al. 1987) and hydrodynamics may influence the success of settlement at different depths, but information on the effect of these factors is sparse. Reduced recruitment observed on artificial collectors placed close to the seabed may be due to enhanced siltation, a major mortality factor for $P$. maximus spat (Thouzeau 1991). Siltation may also partly explain lower recruitment on hydroids located on the bottom.

Compared to results obtained from dead hydroids in

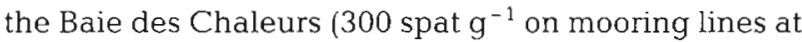
$2 \mathrm{~m}$ from the bottom), abundances of spat on natural filamentous substrata for other pectinid species are very low. Round et al. (1961) obtained 12 Chlamys sp. and 20 Pecten maximus spat per gram (dry wt) of the hydroid Sertularia operculata. Dare \& Bannister (1987) found a maximum of 3.6 Chlamys opercularis spat per gram (dry wt) of Sertularella polyzonias. Compared to results obtained on artificial collectors (Table 2), the abundance of Iceland scallop spat found on dead hydroids in this study is 2.5 times greater than observed for Patinopecten yessoensis in Japan, the highest value reported thus far. Our results are approximately 170 times greater than the highest yield on any other collector (Table 2). Dry hydroids offer ca 3 to 5 times more total area for settlement, for an equivalent weight, than monofilament gill netting (calculated by comparing total area of 2 branches having equal dry weights). Thus, except for Patinopecten yessoensis, differences between the abundance of spat on hydroids and monofilament cannot be explained by the total area available for settlement.

\section{Hypotheses for larvae selectivity for dead hydroids}

Factors leading to greater settlement of spat on dead hydroids than on live hydroids, red algae or monofilament are still unknown. These differences are not caused by variation in area available for settlement among substrata (Fig. 3B). Three other hypotheses might account for the result. Firstly, increased settlement on filamentous structures could be due to passive deposition of larvae resulting from interactions between: (1) flow in the benthic boundary layer; (2) 3-dimensional physical heterogeneity or complexity of the filamentous structures; and (3) microturbulence within and/or around these structures. Larvae may behave as inert particles which may be more efficiently trapped by hydroids than by filamentous algae.
Secondly, larvae could: (1) detect and track a chemical gradient indicating the presence of suitable substrata; or (2) respond to nondirectional chemical cues either by chemotactile reaction or by detecting a diluted chemical product (metabolite or extract) in the seawater. Thirdly, there could be interactions between both passive (hydrodynamic) and active (behavioural) processes acting at different spatial scales (Boudreau et al. in press). Larvae may be carried passively until contact with a substratum, after which they would then test microhabitat quality using chemical cues present in the seawater or on the substratum (i.e. adsorbed or living on the surface), before settling

Passive deposition and near-bottom hydrodynamic processes have recently been investigated by Hannan (1984), Eckman $(1985,1987)$, Butman $(1987,1989)$ and Eckman et al. (1989). Hannan (1984) showed that planktonic larvae of benthic invertebrates may act like passive particles in turbulent near-bottom flows. Havenhand \& Svane (1991) observed that formation of aggregations in the tunicate Ciona intestinalis are probably the result of hydrodynamic processes rather than gregarious larval settlement. Eckman (1987) showed that recruitment of Argopecten irradians was positively correlated to the seawater flux through eelgrass Zostera marina meadows. In the present study, it is possible that both passive deposition and water flux through the filamentous structure of hydroids and algae influence larval settlement and recruitment patterns of Chlamys islandica. This hypothesis is currently being tested in a series of multifactorial experiments in the field and a laboratory flume, using inert particles and plastic structures akin in shape to hydroids and benthic algae.

It is unlikely that planktonic larvae can follow a directional chemical gradient (Crisp \& Meadows 1962, Crisp 1974). However, settling larvae of many species have been observed to respond to nondirectional chemical cues either by a chemotactile reaction (Crisp 1974, Burke 1983, Pawlik 1992) or by detecting a diluted chemical product (metabolite or extract) in seawater (Bonar et al. 1990, Boudreau et al. in press). Metamorphosis rates of Pecten maximus larvae were increased by adding aqueous extracts of certain marine red algae (Chevolot et al. 1991). If newly settled spat respond to the same environmental stimuli at resettlement as do the larvae at settlement, results from our laboratory assays suggest that a chemotactile reaction or detection of diluted chemical products present in seawater surrounding the substratum could be used by larvae during the settlement process. It is still unclear if spat resettle preferentially on dead hydroids in response to chemical cues originating from the nonliving chitinous perisarc, or from microalgae and bacteria fouling the perisarc. Relatively lower spat reset- 
tlement on live hydroids and red algae could also result from a negative response to chemicals used by these organisms as protection against biofouling.

\section{Post-settlement behaviour}

The observed patterns of distribution could also result from a redispersion strategy used by spat to find more appropriate microhabitats after initial settlement on nonsuitable substratum or after reaching a larger size (e.g. Wallace 1981-1982).

Results from our laboratory assays suggest that resettlement behaviour of post-larvae could contribute to the observed distribution of spat in the field. Redispersal would involve 4 phases: (1) dislodgment from the substratumi $(2)$ bysso-pelagic transport and contact with a new substratum; (3) evaluation of habitat suitability; and (4) reattachment by byssal threads. Dislodgment could be active (e.g. Wallace 1981-1982) or passive. Our observation that spat can easily be dislodged by gently shaking the substratum suggests that strong currents or wave action could mechanically dislodge newly settled spat from substrata. Bysso-pelagic transport has been shown in both Mytilus edulis (Sigurdsson et al. 1976) and Macoma balthica (Beukema \& Vlas 1989) spat but has never been observed in pectinid species. Recent laboratory observations showed that spat of Pecten maximus and Aequipecten (Chlamys) opercularis were sometimes able to slow their descent dramatically and it was proposed that this was achieved by the production of a long, fine byssus drifting thread (Beaumont \& Barnes 1992). Postmetamorphic drifting may be a common feature of the life history and ecology of many marine bivalves and gastropods (Martel \& Chia 1991a, b). Both evaluation of habitat suitability and reattachment in Chlamys islandica spat are possible in the field. It could be hazardous to apply results obtained from laboratory single-choice experiments, in still water, directly to the field. However, as spat apparently can recognize substrata by using a chemotactile response, even in turbulent near-bottom flows, such a mechanism could allow identification of suitable substrata and reattachment in the field. Furthermore, Butman et al. (1988), Grassle \& Butman (1989) and Pawlik et al. (1991) showed that larvae of marine invertebrates species are able to evaluate habitat suitability under realistic flow conditions in conducting choice experiments in laboratory flumes.

In the experiment carried out to study the rate of resettlement of spat under controlled conditions (Fig. 5), the significant increase in the rate of resettlement $8 \mathrm{~h}$ after the beginning of the experiment could correspond to an aggregation response to spat that have already settled. Aggregation response has previ- ously been demonstrated in barnacles (Knight-Jones \& Stephenson 1950) and in the polychaete Hydroides dianthus (Scheltema et al. 1981).

\section{Genetic and/or environmental variation in microhabitat preferences}

The results showing that the second most attractive substratum was the one on which spat were originally attached in the field (Fig. 6) could be due to genetic and/or environmental variation in microhabitat preferences. Offspring of the marine annelid Spirorbis borealis preferentially settled on the same species of brown algae as their parents (Doyle 1976). This partially genetically based phenomenon was termed 'habitat loyalty' (Doyle 1976). On the other hand, variation in microhabitat preferences might correspond to conditioning of spat by the substratum on which they first settled. Conditioning at settlement has not been investigated in marine invertebrates. Such effects are common in host location by phytophagous insects (see review by Papaj \& Rausher 1983).

Acknowledgements. Funding for this research has been provided by OPEN, one of the 15 Networks of Centers of Excellence supported by the Government of Canada, by individual NSERC grants and FCAR team grants to E.B., and by NSERC post-doctoral fellowships to M.H. and G.M. We are grateful to Drs E. R. Holm, B. Boudreau and D. Rittschof for seminal discussions and to E. R. Holm for linguistic improvements. We also thank C. Legault, N. Dubé, E. Razurel and J. De Guise for their help in the field and laboratory. Comments from 3 anonymous reviewers have strengthened the paper.

\section{LITERATURE CITED}

Bayne, B. L. (1964). Primary and secondary settlement in Mytilus edulis L. (Mollusca). J. Anim. Ecol. 33: 513-523

Beaumont, A. R., Barnes, D. A. (1992). Aspects of veliger larval growth and byssus drifting of the spat of Pecten maximus and Aequipecten (Chlamys) opercularis. ICES J. mar. Sci. 49: 417-423

Beukema, J. J., Vlas, J. De (1989). Tidal-current transport of thread-drifting postlarval juveniles of the bivalve Macoma balthica from the Wadden Sea to the North Sea. Mar. Ecol Prog. Ser. 52: 193-200

Bonar, D. B., Coon, S. L., Walch, M., Weiner, R. M., Fitt, W (1990). Control of oyster settlement and metamorphosis by endogenous and exogenous chemical cues. Bull. mar. Sci. 46: $484-498$

Boudreau, B, Bourget, E., Simard, Y (in press). Behavioural response of competent lobster postlarvae to odor plumes. Mar. Biol

Bourget, E. (1988). Barnacle larval settlement: the perception of cues at different spatial scales. In: Chelazzi, G., Vannini M. (eds.) Behavioral adaptation to intertidal life. Plenum Press, New York, p. 153-172

Bourne, N., Hodgson, A., Whyte, J. N. C. (1989). A manual for scallop culture in British Columbia. Can. Tech. Rep. Fish. Aquat. Sci. 1694: 1-215 
Brand, A. R. (1991). Scallop ecology: distribution and behaviour. In: Shumway, S. E. (ed.) Scallops: biology, ecology and aquaculture. Elsevier, New York, p. 517-584

Brand, A. R., Paul, J. D., Hoogesteger, J. N. (1980). Spat settlement of the scallops Chlamys opercularis (L.) and Pecten maximus (L.) on artificial collectors. J. mar biol. Ass. U.K. 60: $379-390$

Buestel, D., Dao, J. C., Lemarie, G. (1979). Collecte de naissain de pectinidés en Bretagne. Rapp. P.-v. Réun. Cons. int. Explor. Mer 175: 80-84

Burke, R. D. (1983). The induction of metamorphosis of marine invertebrate larvae: stimulus and response. Can. J. Zool. 61: 1701-1719

Butman, C. A. (1987). Larval settlement of soft-sediment invertebrates: the spatial scales of pattern explained by active habitat selection and the emerging role of hydrodynamical processes. Oceanogr. mar. Biol. A. Rev. 25: $113-165$

Butman, C. A. (1989). Sediment-trap experiments on the importance of hydrodynamical processes in distributing settling invertebrate larvae in near-bottom waters. J. exp. mar. Biol. Ecol. 134: 37-88

Butman, C. A., Grassle, J. P., Webb, C. M. (1988). Substrate choices made by marine larvae settling in still water and in a flume flow. Nature 333: 771-773

Chevolot, L., Cochard, J. C., Yvin, J. C. (1991). Chemical induction of larval metamorphosis of Pecten maximus with a note on the nature of naturally occurring triggering substances. Mar. Ecol. Prog. Ser. 74: 83-89

Cliche, G., Giguère, M., Picard, P. (1991). Spatial and temporal variations of the scallop (Placopecten magellanicus) settlement in Magdalen Islands (Québec, Canada). 8th int. Pectinid Workshop, Cherbourg, France 21-29 May 1991

Conover, W. J. (1980). Practical nonparametric statistics, 2nd edn. John Wiley, New York

Crisp, D. J. (1974). Factors influencing the settlement of marine invertebrate larvae. In: Grant, P. T., Mackie, A. M. (eds.) Chemoreception in marine organisms. Academic Press, New York, p. 177-265

Crisp, D. J., Meadows, P. S. (1962). The chemical basis of gregariousness in cirripedes. Proc. R. Soc. Lond. B. 156: $500-520$

Dare, P. J., Bannister, R. C. A. (1987). Settlement of scallop, Pecten maximus, spat on natural substrates off south-west England: the hydroid connection (abstract only). In: Beaumont, A. R., Mason, J (eds.) 6th int. Pectinid Workshop, Menai Bridge, Wales 9-14 April 1987. Comm. Meet. int. Coun. Explor. Sea C.M.-ICES 1987/K:3

Doyle, R. W. (1976). Analysis of habitat loyalty and habitat preference in the settlement behavior of planktonic marine larvae. Am. Nat. 110: 719-730

Eckman, J. E. (1985). Flow disruption by an animal-tube mimic affects sediment bacterial colonization. J. mar. Res. 43: $419-435$

Eckman, J. E. (1987). The role of hydrodynamics in recruitment, growth, and survival of Argopecten irradians (L.) and Anomia simplex (D'Orbigny) within eelgrass meadows. J. exp. mar. Biol. Ecol. 106: 165-191

Eckman, J. E., Duggins, D. O., Sewell, A. T. (1989). Ecology of understory kelp environments. I. Effects of kelps on flow and particle transport near the bottom. J. exp. mar. Biol. Ecol. 129: 173-187

Grassle, J. P., Butman, C. A. (1989). Active habitat selection by larvae of the polychaetes, Capitella spp. I and II, in a laboratory flume. In: Ryland, J. S., Tyler, P. A. (eds.) Reproduction, genetics and distributions of marine organisms. Proc. 23rd Eur. mar. biol. Symp. Olsen and Olsen,
Fredensborg, p. 107-114

Hannan, C. A. (1984). Planktonic larvae may act like passive particles in turbulent near-bottom flows. Limnol. Oceanogr. 29: 1108-1116

Havenhand, J. N., Svane, I. (1991). Roles of hydrodynamics and larval behaviour in determining spatial aggregation in the tunicate Ciona intestinalis. Mar. Ecol. Prog. Ser. 68: $271-276$

Knight-Jones, E. W., Stephenson, J. P. (1950). Gregariousness during settlement in the barnacle Elminius modestus Darwin. J. mar biol. Ass. U.K. 29: 281-297

Larsen, P. F., Lee, R. M. (1978). Observations on the abundance, distribution and growth of postlarval sea scallops, Placopecten magellanicus on Georges Bank. Nautilus 92: $112-116$

Martel, A., Chia, F. (1991a). Foot-raising behaviour and active participation during the initial phase of post-metamorphic drifting in the gastropod Lacuna spp. Mar. Ecol. Prog. Ser. 72: $247-254$

Martel, A., Chia, F. (1991b). Drifting and dispersal of small bivalves and gastropods with direct development. J. exp. mar. Biol. Ecol. 150: 131--147

Merril, A. S., Edwards, R. L. (1976). Observations on mollusks from a navigation buoy with special emphasis on the sea scallop Placopecten magellanicus. Nautilus 90: 54-61

Minchin, D. (1992). Biological observations on young scallops, Pecten maximus. J. mar. biol. Ass. U.K. 72: 807-819

Naidu, K. S., Cahill, F. M., Lewis, D. B. (1981). Relative efficacy of two artificial substrates in the collection of sea scallop (Placopecten magellanicus) spat. J. Wld Maricul. Soc. 12: $165-171$

Orensanz, J. M., Parma, A. M., Iribarne, O. O. (1991). Population dynamics and management of natural stocks. In: Shumway, S. E. (ed.) Scallops: biology, ecology and aquaculture. Elsevier, New York, p. 625-689

Papaj, D. R., Rausher, M. D. (1983). Individual variation in host location by phytophagous insects. In: Ahmad, S. (ed.) Herbivorous insects: host-seeking behavior and mechanisms. Academic Press, New York, p. 77-124

Pawlik, J. R. (1992). Chemical ecology of the settlement of benthic marine invertebrates. Oceanogr. mar. Biol. A. Rev. 30: $273-335$

Pawlik, J. R., Butman, C. A., Starczak, V. R. (1991). Hydrodynamic facilitation of gregarious settlement of a reefbuilding tube worm. Science 252: 421-424

Phleger, C. F., Cary, S. C. (1983). Settlement of spat of the purple-hinge rock scallop Hinnites multirugosus (Gale) on artificial collectors. J. Shellfish Res. 3: 71-73

Rittschof, D., Branscomb, E. S., Costlow, J. D. (1984). Settlement and behavior in relation to flow and surface in larval barnacles, Balanus amphitrite Darwin. J. exp. mar Biol. Ecol. 82: 131-146

Roberts, D., Rittschof, D., Holm, E., Schmidt, A. R. (1991). Factors influencing initial larval settlement: temporal, spatial and surface molecular components. J. exp. mar. Biol. Ecol. 150: 203-211

Round, F. E., Sloane, J. F., Ebling, F. J., Kitching, J. A. (1961). The ecology of Lough Ine X. The hydroid Sertularia operculata (L.) and its associated flora and fauna: effects of transference to sheltered water. J. Ecol. 49: 617-629

Ruzzante, D. E., Zaixso, H. E. (1985). Settlement of Chlamys tehuelchus (D'Orb.) on artificial collectors. Seasonal changes in spat settlement. Mar. Ecol. Prog. Ser. 26: 195-197

Sause, B. L., Gwyther, D., Burgess, D. (1987). Larval settlement, juvenile growth and the potential use of spatfall indices to predict recruitment of the scallop Pecten alba 
Tate in Port Phillip Bay, Victoria, Australia. Fish. Res. 6: $81-92$

Scheltema, R. S., Williams, I. P., Shaw, M. A., Loudon, C. (1981). Gregarious settlement by the larvae of Hydroides dianthus (Polychaeta: Serpulidae). Mar. Ecol. Prog. Ser. 5: $69-74$

Sigurdsson, J. B., Titman, C. W., Davis, P. A. (1976). The dispersal of young post-larval bivalve molluscs by byssus threads. Nature 262: 386-387

Thorarinsdottir, G. G. (1991). The Iceland scallop, Chlamys islandica (O. F. Müller) in Breidafjördur, west Iceland. I. Spat collection and growth during the first year. Aquaculture 97: 13-23

Thouzeau, G. (1989). Determinisme du pré-recrutement de

This article was submitted to the editor
Pecten maximus L. en baie de Saint-Brieuc. Ph.D. thesis, Université de Bretagne Occidentale, Brest

Thouzeau, G. (1991). Experimental collection of postlarvae of pecten maximus (L.) and other benthic macrofaunal species in the Bay of Saint-Brieuc, France. I. Settlement patterns and biotic interactions among the species collected. J. exp. mar. Biol. Ecol. 148: 159-179

Ventilla, R. F. (1982). The scallop industry in Japan. Adv. mar Biol. 20: 309-382

Wallace, J. C. (1981-1982). The culture of the Iceland scallop, Chlamys islandica (O. F. Müller). I. Spat collection and growth during the first year. Aquaculture 26: 311-320

Zar, J. H. (1984). Biostatistical analysis, 2nd edn. PrenticeHall, Englewood Cliffs

Manuscript first received: March 19, 1993

Revised version accepted: June 22, 1993 